\title{
What is new on the physiopathology of endometrosis in the mare?
}

\author{
Maria Rosa Rebordão 1,2, Cátia Pereiral, António Galvão 1,3, Pedro Pinto Bravo 1,2, Anna Szóstek³, Dariusz Jan Skarzynski³ \\ and Graça Ferreira-Dias ${ }^{1}$ \\ ' C.I.I.S.A., Faculty of Veterinary Medicine, University of Lisbon, Lisbon, Portugal \\ ${ }^{2}$ Coimbra College of Agriculture, Coimbra, Portugal \\ ${ }^{3}$ Institute of Animal Reproduction and Food Research of PAS, Olsztyn, Poland
}

\begin{abstract}
Summary: The mare endometrium is a highly regenerative tissue that undergoes remodelling events during physiological events like endometrial regeneration, uterine involution, and parturition. In addition, the equine endometrium presents the particularity of developing fibrosis (collagen deposition) in the stroma, leading to endometrosis, responsible for early embryo loss. Endometrosis pathogenesis is not fully understood. Since reservoirs of somatic stem cells (SSC) are present in adult tissues capable of constant mature cell production or post injury regeneration, we evaluated the presence of cells positive for undifferentiated markers (Oct-4, Sox-2) in mare endometria. Both markers were expressed in differentiated glandular epithelial cells and stroma cells, in the presence or absence of endometrosis, in the different phases of the estrous cycle. The ability of equine neutrophils (PMN) to form neutrophils extracellular traps (NETs) might be a mechanism to kill some bacteria responsible for mare endometritis. Nevertheless, NETs proteins myeloperoxidase, elastase, and cathepsin G might also contribute for fibrosis establishment in the mare endometrium. Besides, NETs components and cytokine CTGF are involved in TGFbl and TIMP- 1 production and up regulate the transcription of genes related with pathological collagen proteins deposition characteristic of fibrosis and likely related with TGFbl fibrogenic action. Understanding the complexity of cytokines, NETs and SSC driven mechanisms of fibrosis in mare endometrium is important to unravel endometrosis pathogenesis.
\end{abstract}

Keywords: Neutrophil extracellular traps / cytokines / mare / endometrium / endometrosis / somatic / stem cells.

Correspondence: Prof. Graça Ferreira-Dias, Faculdade de Medicina Veterinária, Av. Universidade Técnica, $1300-477$ Lisboa, Portugal. E-mail:gmlfdias@fmv.ulisboa.pt

Citation: Rebordão M. R., Pereira C., Galvão A., Pinto Bravo P., Szóstek A., Skarzynski D. J., Ferreira-Dias G. (2014) What is new on the physiopathology of endometrosis in the mare? Pferdeheilkunde 30, 15-18

\section{Introduction}

Throughout the estrous cycle and post-partum uterine involution, a coordinated vascular and non-vascular growth and regression of the mare endometrium take place (Roberto da Costa et al. 2007a,b, Agrícola et al. 2010). Some of the remodeling events that occur naturally during endometrial regeneration and post-partum uterine involution, are mostly under steroid hormones influence (Agrícola et al. 2010, Ferreira-Dias et al. 2001). The well developed regenerative capacities of the equine endometrium, can be related to cell proliferation, caspase- 3 mediated apoptosis, and cytokines actions that happen differently throughout the estrous cycle (Roberto da Costa et al. 2007b, Galvão et al., 2012). In fact, the coordinated action of ovarian hormones and cytokines, such as tumour necrosis factor (TNF)- $\alpha$, Fas Ligand (FasL) and interferon $\beta$ (IFN)- $\beta$ may regulate secretory, proliferative and angiogenic functions in mare endometrium (Galvão et al. 2012). These processes of endometrium regeneration are similar to the ones that happen during tissue damage and repair in other organs after injury or associated to numerous pathologies (Salamonsen 2003). In fact, the mare endometrium, in response to bacteria or to non-infectious stimuli, such as semen that reaches the uterus at breeding, has the particularity of developing fibrosis (collagen deposition) in the stroma, leading to endometrosis (Kenney 1992, Hoffmann et al. 2009). This degenerative chronic condition is defined as an active or inactive fibrosis process that develops around the endometrial glands and/or in the stroma, often associated with pathological alterations in the endometrial glands within fibrotic foci (Hoffmann et al. 2009). Also, within the fibrotic areas, an estrous cycle asynchronous uterine protein (uteroglobin, uterocalin, calbindin, uteroferrin) expression pattern, with signs of endometrial maldifferentiation, has been described (Lehmann et al. 2011). Besides, fibrotic stromal cells depict a reduced expression of estradiol and progesterone receptors in comparison to healthy endometrium (Hoffmann et al. 2009). We have shown that in the course of endometrosis, significant changes in mRNA transcription of prostaglandin (PG) synthases and PG production in mare endometrium could lead to estrous cycle disorders and early embryo loss (Szóstek et al. 2012). Besides, alterations in the expression of interleukins (IL)- $\alpha, \mathrm{IL}-\beta, \mathrm{IL}-6$ and their receptors, and in endometrial secretory function may be responsible for a deleterious effect on uterine microenvironment and subsequent sub-fertility or infertility in endometrosis (Szóstek et al. 2013). Thus, it appears that affected areas of endometrosis become independent of control mechanisms acquiring specific differentiation dynamics (Lehmann et al. 2011). As a result, endometrosis renders the endometrium incapable of adequate function, crucial for survival of the young embryo, leading ultimately to early pregnancy loss. In fact, this pathologic condition has been considered as the main cause of infertility in the mare.

\section{Somatic Stem Cells}

Many facets of the pathophysiology of fibrosis formation are largely unknown. It is not understood why some mares deve- 
lop endometrial fibrosis with aging, parity and recurrent microbial challenge, while others do not. In human endometrium, a putative role of somatic stem cells (SSC) has been ascribed to the pathophysiology of endometriosis, endometrial hyperplasia, cancer and adenomyosis (Cervelló et al. 2011). Reservoirs of SSC are only present in adult tissues capable of constant mature cell production or post injury regeneration (Lemischka 2001). Since in women, endometrial glands are the residence of epithelial progenitor cells contributing to monthly reepithelialization of the uterine surface (Kaitu u-Lino et al. 2010), this can also hold true for the mare. Therefore, we hypothesize that endometrial SSC might act in dissimilar ways in different mare endometria, different phases of the estrous cycle. Since reservoirs of somatic stem cells (SSC) are present in adult tissues capable of constant mature cell production or post injury regeneration, we evaluated by immunohistochemistry in mare endometria the presence of cells positive for the markers Oct-4 or POU5F1 and Sox-2. These are transcription factors involved in self-renewal or pluripotency of undifferentiated embryonic stem cells. These preliminary data show that Oct-4 was expressed more strongly in the cytoplasm of differentiated glandular epithelial cells and more weakly in stroma cells, in contrast to nuclear staining reported for biological active embryonic undifferentiated cells (Cauffman et al. 2005). Thus, in the mare endometrium, as in humans, the presence of Oct-4 protein may not be sufficient for identifying undifferentiated cell lines (Cauffman et al. 2005). In the present experiment, Sox-2 expression was present not only in the cytoplasm but also in the nucleus of differentiated glandular epithelial cells, and in a strong manner in the nucleus of stroma cells. These positive staining of both markers occurred in the presence or absence of endometrosis, in the follicular and luteal phases of the estrous cycle (Fig. 1). Recently, it was shown that mare endometrium with endometrosis was able to incorporate and widely distribute equine adipose tissue derived mesenchymal stem cells after uterine inoculation (Mambelli et al., 2013). Homing of these SSC occurred in the area of fibrosis tissue, uterine glandular epithelium, basal membrane of uterine glands in uterine horns and body (Mambelli et al. 2013). These findings may suggest the importance of SSC on the mare endometrium and for future treatments of infertility.

\section{Equine Neutrophils extracellular traps and endometro- sis}

Regardless of the cause of endometritis in the mare, the presence of fluid in the uterine lumen and neutrophils (PMN) in the endometrium are common findings (Woodward et al. 2012). Soon after mating, the physiologic uterine inflammation induced by semen and bacteria drives PMN towards the mare uterus to resolve this condition. Currently, besides the well known classical role of PMN on bacteria phagocytosis, a novel paradigm in innate immunity is the ability of PMN to form neutrophil extracellular traps called NETs (Lögters et al. 2009). This is accomplished by PMN releasing their DNA and DNA-associated molecule complexes carrying nucleic and cytoplasmic proteins that trap and kill bacteria at the infection site (Lögters et al., 2009). This is an active process called NETosis, and unlike necrosis or apoptosis, it involves antimicrobial and proinflammatory responses. Even though NETs may function as a first line of defense, preventing bacterial infection to be spread, they also release molecules that may contribute to damage within inflamed tissues (Lögters et al., 2009). Among those, myeloperoxidase, elastase and cathep$\sin G$, are proteins with antimicrobial properties (Lögters et al., 2009). Therefore, we have put forth the hypothesis that NETs persistence in the course of endometritis might be one of the causes for collagen fibrosis pathogenesis in the endometrium. In fact, we have shown that in vitro stimulated equine PMN are able to release NETs (Rebordão et al. 2012) (Fig. 2). When bacteria causing endometritis in the mare, such as Streptococcus zooepidemicus, Escherichia coli or Staphylococcus capitis were in contact with horse PMN, all were able

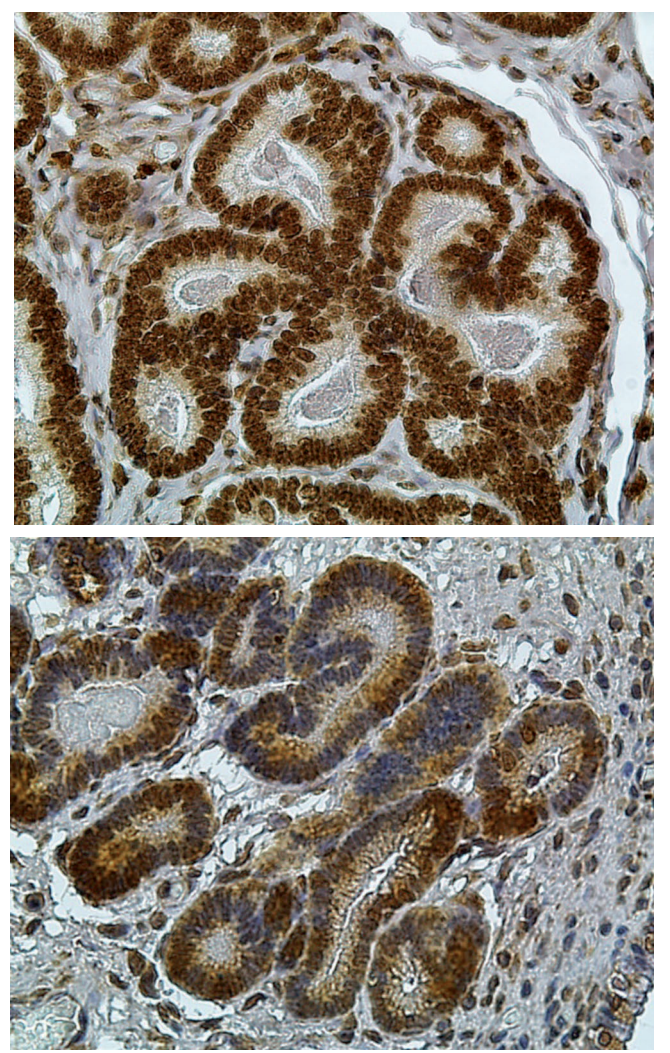

Fig. 1 - Representative images of equine endometrium immunostained for the presence of Sox-2 (above; Mag=40x) on the nucleus and cytoplasm of epithelial glandular cells and stroma; and Oct-4 (below; Mag=40x) on the cytoplasm of epithelial glandular cells and stroma. / Repräsentative immunhistologische Bilder aus dem Stutenendometrium: Oben: Sox-2 nachweisbar im Kern und Zytoplasma der Uterindrüsenepithelien (Gerätevergrößerung 40x) Unten: Oct-4 nachweisbar im Zytoplasma der Uterindrüsenepithelien (Gerätevergrößerung 40x)

to stimulate NETs release (9). Bacteria Streptococcus zooepidemicus and Escherichia coli, which are the main microorganisms responsible for mare endometritis (Wittenbrink et al. 2008), were the ones that induced less NETs in contrast to Staphylococcus capitis that is not a so common endometritis causing pathogen. Thus, this in vitro study shows that NETs formation ability by horse PMN might be a mechanism to fight some microorganisms responsible for mare endometritis.

As a follow up, to better understand NETs role on modulation of the inflammatory response in the uterus and endometrial fibrosis pathogenesis, mare endometrium explants were exposed in vitro to NETs protein components cathepsin G, 
elastase and myeloperoxidase (Rebordão et al. 2013a,b). Due to the capacity of tissue inhibitor of metalloproteinase (TIMP-1) and transforming growth factor $\alpha$ (TGF $\alpha$ ) to modulate genes involved in fibrosis formation (Gressner et al. 2007, Zhu et al. 2012), they were used as fibrosis markers in mare endometrium (Rebordão et al. 2013a,b). As a result, we have shown that estrous cycle might influence endometrial fibrosis establishment in the mare. Specifically, in the follicular phase, when a physiologic influx of PMN occurs in the uterus, a long term exposure of the endometrium to myeloperoxidase and elastase raised TIMP-1 (Rebordão et al. 2013a). However, TGF $\alpha$ production was stimulated over time by myeloper-

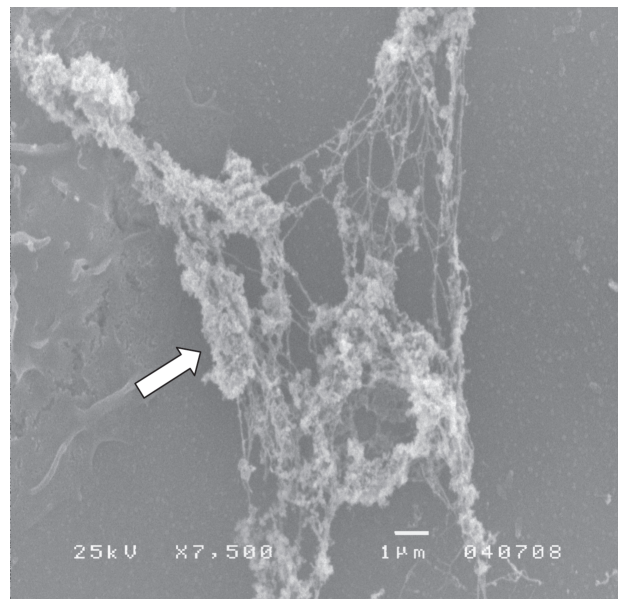

Fig. 2 - Ultrastructure of a NET evaluated by scanning electron microscopy (white arrow). Mag=7,500X. / Ultrastruktur eines NET mit Hilfe des Rasterelektronenmikroskops (weißer Pfeil). Gerätevergrößerung 7500x.

oxidase (Rebordão et al. 2013a). In the luteal phase, cathepsin G up-regulated TIMP and TGF $\alpha$ production between 24 and $72 \mathrm{~h}$ (Rebordão et al. 2013a). Prolonged exposure of mare endometrium to cathepsin $G$, elastase and myeloperoxidase up regulated type I collagen mRNA transcription, indicating fibrosis establishment (Rebordão et al. 2013c). In the luteal phase, a chronic exposure to some NETs components increased prostaglandin F2 $\alpha$ (PGF2 $\alpha$ ), which might explain premature luteolysis associated to endometritis in the mare (Rebordão et al. 2013b). In conclusion, contradictory roles may be ascribed to NETs, since even though they fight bacteria at the infection site, they may also induce deleterious effects by establishing endometrosis in the mare.

\section{Pro-fibrotic Cytokines}

The pathogenesis of tissue fibrosis is regulated by interactions with an intricate network of profibrotic cytokines, extracellular matrix components, inflammatory cells, and hormones (Atamas 2002). In inflamed tissues, fibroblasts interact with extracellular matrix and other cells through soluble factors, such as cytokines, to produce fibrosis (Atamas 2002). It is well established that cytokines regulate fibrosis through a dual effect, by stimulating fibroblast proliferation and collagen production (Atamas 2002). In fact, connective tissue growth factor (CTGF) and transforming growth factor (TGF $\alpha$ ) are among the most potent profibrotic cytokines (Atamas 2002). Since they are powerful activators of collagen production and fibro- sis establishment, we investigated their action on mare endometrium fibrosis development. Luteal phase endometrium explants exposed to CTGF increased in vitro TGF $\alpha$ and TIMP-1 production (Rebordão et al. $2013 a, b)$. In addition, up regulation of gene transcription of TGF $\beta 1$ receptor 1 and type I and III collagen, related with pathological collagen proteins deposition characteristic of fibrosis and likely related with TGF $\beta 1$ fibrogenic action, was also observed (Rebordão et al. 2013c). In the follicular phase, while in vitro TIMP-1 production by the endometrium was increased with CTGF over time (Rebordão et al. 2013a,b), no effect was observed on TGF $\alpha$. These data suggest a putative involvement of CTGF in mare endometrosis establishment (Rebordão et al. $2013 a, b, c)$.

Understanding the complexity of cytokines, NETs and SSC driven mechanisms of fibrosis in mare endometrium is important to unravel endometrosis pathogenesis. Besides, identification of potential molecular targets for future pharmacological and regenerative medicine approaches for prophylaxis and treatment of endometrosis in the mare should be sought.

\section{Acknowledgement}

Grant support from FCT, Portugal: "PTDC/CVT/121805/ 2010", "EXPL/CVT-REP/1485/2012", Bilateral cooperation Portugal-Poland-"Project 6818"; and from the National Research Center of Poland: Maestro grant to DJS, No 2011 / 02/A/NZ5/00338.

\section{References}

Agrícola R., Pessa P., Pereira M., Medeiros J. A. S., Ferreira-Dias G. (2010) Cytologic and angiogenic aspects of uterine involution in the post-partum mare. Proceedings 6th International Conference on Equine Reproductive Medicine (ICERM), Leipzig, Germany. pp: 299-303

Atamas S. (2002) Complex cytokine regulation of tissue fibrosis. Life Sciences 72,631-643

Cauffman G., Van de Velde H., Liebaers I. and Van Steirteghem A. (2005) Oct-4 mRNA and protein expression during human preimplantation development. Mol. Hum. Reprod. 11, 173-181

Cervelló I., Aymara M., Gil-Sanchis C., Peris L., Faus A., Saunders P. T. K., Critchley H. O. D., Simón C. (2011) Reconstruction of endometrium from human endometrial side population cell lines. PLos One Volume 6, e21221.

Ferreira-Dias G., Serrão P.M., Costa Durão J., Robalo Silva J. (2001) Microvascular development and growth of the uterus during the estrous cycle in the mare. American Journal of Veterinary Research 62(4),526-530.

Galvão A., Valente L., Skarzynski D.bJ., Szóstek A., Piotrowska-Tomala K.bK., Ramilo D., Rebordão M.bR., Mateus L., Ferreira-Dias G. (2012) Effect of cytokines and ovarian steroids on equine endometrium: an in vitro study. Reproduction, Fertility and Development 25(7),985-97.

Gressner O. A., Weiskirchen R., Gressner A.bM. (2007) Biomarkers of liver fibrosis: clinical translation of molecular pathogenesis or based on liver-dependent malfunction tests. Clin. Chim. Acta 381, 107-113

Hoffmann C., Ellenberger C., Costa Mattos R, Aupperle H., Dhein S., Stief B., Schoon H-A. (2009) The equine endometrosis: New insights into the pathogenesis. Anim. Reprod. Sci. 111,261-278

Kaitu'u-Lino T. J., Ye L., Gargett C. E. (2010). Reepithelialization of the uterine surface arises from endometrial glands: evidence from a functional mouse model of breakdown and repair. Endocrinology $151,3386-3395$ 
Kenney R. M. (1992) The aetiology, diagnosis, and classification of chronic degenerative endometritis. In: Hughes JP. (ed) Workshop on equine endometritis. Newmarket, UK, Equine Vet. J. 25,186

Lehmann J., Ellenberger C., Hoffmann C., Bazer F. W., Klug J., Allen W. R., Sieme H., H-A Schoon (2011) Morpho-functional studies regarding the fertility prognosis of mares suffering from equine endometrosis. Theriogenology 76,1326-1336

Lemischka I. (2001) Stem cell dogmas in the genomics era. Rev. Clin. Experim. Hematol. 5,15-25

Lögters T., Margraf S., Altrichter J., Cinatl J., Mitzner S., Windolf J., Scholz M. (2009) The clinical value of neutrophil extracellular traps. Med. Microbiol. Immunol. 198, 211-219

Mambelli L. I., Winter G. H. Z., Kerkis A., Malschitzky E., Mattos R. C., Kerkis I. (2013) A novel strategy of mesenchymal stem cells delivery in the uterus of mares with endometrosis. Theriogenology 79, 744-750

Rebordão M. R., Galvão A., Serrão P. M., Carneiro C., Leitão A., Vilela C., Ferreira-Dias G. (2012) Neutrophil extracellular traps and endometritis in the mare. 6th Leipzig Expertworkshop on Equine Reproductive Medicine-Equine Endometritis. 20 Jan 2012, Leipzig, Germany. Pferdeheilkunde 28, 87

Rebordão M. R., Galvão A., Amaral A., Szóstek A., Lukasik K., Piotrowska-Tomala K., Skarzynski D. J., Ferreira-Dias G. (2013a) Estrous cycle phases on mare endometrium secretory function and fibrosis markers (TIMP 1 and TGFb 1) after neutrophil extracellular traps and cytokines action. 17th Conference of European society for Domestic Animal Reproduction, 12-14 Sept 2013, Bologna, Italy. Reprod. Dom. Anim. 48 Suppl 1, 114

Rebordão M. R., Galvão A., Szóstek A., Lukasik K., PiotrowskaTomala K., Skarzynski D. J., Ferreira-Dias G. (2013b) Neutrophil extracellular traps and cytokines on mare endometrium prostaglandins and fibrosis markers TIMP and TGFb 1. 2nd Joint GermanPolish Conference on Reproductive Medicine/ 46th Annual Conference of Physiology and Pathology of Reproduction", 27 Feb- 1 Mar 2013, Gdánsk, Poland.pp:54.

Rebordão M. R., Galvão A., Amaral A., Szóstek A., Lukasik K., Piotrowska-Tomala K., Skarzynski D. J., Ferreira-Dias G. (2013c) Neutrophil extracellular traps and cytokines on the expression of genes involved in mare endometrosis. Conference on "Endometritis as a cause infertility in domestic animals: new diagnostic and therapeutic strategies", 6-8 Oct 2013, Olsztyn, Poland. In press.

Roberto da Costa R. P, Ferreira-Dias G., Mateus L., Korzekwa A., Andronowska A., Platek R., Skarzynski D. J. (2007a) Endometrial nitric oxide production and nitric oxide synthases in the equine endometrium: relationship with microvascular density during the estrous cycle. Dom. Anim. Endocrinol. 32,287-302

Roberto da Costa S. E., Serrão P. M., Monteiro S., Pessa P., FerreiraDias G. (2007b) Caspase-3 mediated apoptosis and cell proliferation in the equine endometrium during the oestrous cycle. Reprod. Fertil. Develop. 19,925-932

Salamonsen L. A. (2003). Tissue injury and repair in the female human reproductive tract. Reproduction 125, 301-31 1
Szóste K. A. Z., Siemienuch M. J., Galvão A. M., Kukasik K., Ferreira-Dias G.. Skarzynski D. J. (2012) mRNA transcription of prostaglandin synthases and their products in the equine endometrium in the course of fibrosis. Theriogenology 78,768-776

Szóstek A. Z., Lukasik K., Ferreira-Dias G. M.. Skarzynski D. J. (2013) Impairment of the interleukin system in equine endometrium in the course of endometrosis. Biol. Reprod.. In press.

Wittenbrink M. M., Hoelzle K., Hoelzle L. E. (2008) What s new in bacteriology of the mare s genital tract. Pferdeheilkunde 24, 53-55.

Woodward E. M., Christoffersen M., Campos J., Squires E. L., Troedsson M. H. T. (2012) Susceptibility to persistent breedinginduced endometritis in the mare: Relationship to endometrial biopsy score and age, and variations between seasons. Theriogenology 78, 495-501

Zhu C. L., Li W. T., Li Y., Gao R. T. (2012) Serum levels of tissue inhibitor of metalloproteinase-1 are correlated with liver fibrosis in patients with chronic hepatitis B. Journ. Digest. Diseas. 13, 558-563

\section{Zusammenfassung}

Das Stutenendometrium ist ein hoch regeneratives Gewebe, das physiologischen Umbauprozessen im Zuge von Regeneration, Uterusinvolution und Geburt unterliegt. Darüber hinaus besteht beim Pferd die Besonderheit, dass sich im endometrialen Stroma Fibrosen (Kollagenablagerungen) entwickeln, die zur Endometrose führen, welche verantwortlich für den frühen embryonalen Verlust ist. Die Pathogenese der Endometrose ist nicht vollständig geklärt. Da es Reserven von somatischen Stammzellen (SSC) in adulten Geweben gibt, die in der Lage sind, konstant reife Zellen zu produzieren oder nach Verletzungen zu regenerieren, haben wir die Anwesenheit von Zellen im Stutenendometrium ausgewertet, die positiv für undifferenzierte Marker (Oct-4, Sox-2) sind. Beide Marker wurden in differenzierten Drüsenepithelzellen und Stromazellen exprimiert, in Gegenwart oder Abwesenheit einer Endometrose und in den verschiedenen Phasen des Zyklus. Die Fähigkeit der equinen neutrophilen Granulozyten (PMN) "neutrophils extracellular traps" (NETs) zu formieren, könnte ein Mechanismus sein, um einige Bakterien abzutöten, die für die equine Endometritis verantwortlich sind. Dennoch könnten die NETs Proteine Myeloperoxidase, Elastase und Kathepsin G auch zur Entstehung der Fibrosen im Stutenendometrium beitragen. Zudem sind die NETs-Komponenten und Zytokin CTGF an der TGF $\beta 1$ und TIMP-1-Produktion beteiligt und regulieren die Transkription von Genen auf, die mit pathologischen Ablagerungen von Kollagenproteinen, welche charakteristisch für Fibrosen sind, und wahrscheinlich mit der TGF $\beta 1$ fibrogenen Aktion in Zusammenhang stehen. Das Verständnis der Komplexität der von Zytokinen, NETs und SSC angetriebenen Mechanismen der equinen endometrialen Fibrose ist wichtig, um die Pathogenese der Endometrose zu entwirren

Schlüsselwörter: Neutrophil extracellular traps / Zytokine / Pferdestute / Endometrium / Endometrose / somatische Stammzellen / Reproduktion 